\title{
Lender-Borrower Relationships In Austrian Banks: An Exploratory Study Of Distressed Loans
}

\author{
Christine Mitter, Salzburg University of Applied Sciences, Austria \\ Andrea Weidinger, Salzburg University of Applied Sciences, Austria \\ Johan Coetzee, University of the Free State, South Africa
}

\begin{abstract}
Drawing on interviews with the heads of the workout units of a non-probability sample of 12 Austrian banks, this exploratory study investigates the relationship between distressed borrowers and their banks. The heterogeneous sample was selected based on several structural factors with one main criterion being the regional or international focus of the respective bank. The findings suggest that internal loan workouts are the predominant and preferred strategy amongst most interviewed banks. However, while the international banks do not restructure at all costs, working out the distressed nature of the loan appears to be the overarching objective of regional and smaller banks. By implication, the regional banks were found to be more 'hands-on' when dealing with distressed loans than their larger international counterparts. Active loan workout processes and specialised units were also found to be part of both international and regional banks' strategies to deal with distressed loans. The regional banks were also more inclined to include the relationship banker in the workout process and tend to take longer to workout distressed loans.
\end{abstract}

Keywords: Distressed Loans; Relationship Banking; Loan Workout; Bank Pool

\section{INTRODUCTION}

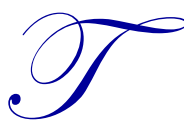

he quality of a lender's loan book is central to ensuring that the risk it faces is managed effectively. When borrowers experience problems, be it cash flow or operational, the inability to service their debt in turn places the lender under pressure. Besides the obvious losses with regards to interest income, the lender is forced to become actively involved in recouping as much from the distressed loan as possible. In addition, these losses result in reputational effects that may have a knock-on effect on the sourcing of loans going forward.

Therefore, the ability of a bank to manage the credit risk inherent to its loan book is part and parcel of the normal operations of a bank. The Global Financial Crisis (GFC) of 2007-2009 and the subsequent sovereign debt crisis in the Eurozone have placed more pressure on borrowers. Hence, the quality of bank assets and specifically loans has deteriorated significantly since the advent of the GFC (Nkusu 2011; Beck et al. 2013). This has led to a significant increase in the percentage of distressed loans on the balance sheets of banks (Ernst \& Young 2013). Nonperforming loans (NPLs) and sub-performing loans (SPLs) are thus unattractive to banks for a number of reasons. Apart from write-offs that impair profit and the balance sheet, these loans are associated with additional expenses that result from their monitoring, the negotiation of workout arrangements, the disposal of granted collateral and diverted focus of the bank's managers (Berger and DeYoung 1997). It is therefore not in the best interests of the bank to have loans that are not performing as they carry a higher degree of risk. Since Basel II stipulates higher risk weights for borrowers with a low creditworthiness, distressed loans increase the related capital requirements of banks (Basel Committee on Banking Supervision 2004). Together with the higher capital demands placed on banks by the Basel III requirements, distressed loans are associated with significantly higher costs of capital for the bank. These costs ultimately result in banks holding more capital, which in itself is expensive. Furthermore, Basel III 
makes explicit mention of improving both the quantity and quality of capital held (Basel Committee on Banking Supervision 2011) - the extent of this is therefore directly affected by the underlying quality of the loans granted by a bank. Consequently, banks have been forced to become more vigilant to identify and manage the ensuing credit losses associated with distressed loans.

Previous research mainly focused on the determinants of problem loans and linked their volume to macroeconomic factors such as GDP (growth), public debt, unemployment, interest rates and credit terms as well as bank-specific factors such as ownership structure, management quality and performance (e.g., Shehzad et al. 2010; Nkusu 2011; Louzis et al. 2012; Filip 2014; Chaibi and Ftiti 2015). Another strand of literature analysed the structure of various markets for distressed loans mainly in the US but also Asian and European countries (e.g., McIver 2005; Schalast et al. 2006; Altman 2014) and problem loan transactions in these markets (e.g., Schäfer 2007; Dick 2010). While some papers investigated distressed loans from a public policy perspective in order to develop bank regulation and government intervention (e.g., Istrate et al. 2007; Nkusu 2011), others stressed the lender-client relationship within problem loans and analysed the role of the bank in the restructuring process. This latter strand of research mainly focused on firm clients and therefore the bank's impact on and measures applied in the corporate restructuring process (e.g., Gilson 1990; Franks and Sussman 2005; Davydenko and Franks 2008, Blazy et al. 2014). However, distressed loans comprise a vast array of loan types ranging from business loans over mortgages to consumer loans. Moreover, there is a relative paucity of empirical studies on how banks manage their distressed loans in general, how they organise the workout process and which measures they undertake in order to minimise loan losses. In this paper we address these concerns and draw on a qualitative study among Austrian banks to indepth investigate the processes in managing and dealing with distressed loans.

More specifically, the paper aims to:

1. provide insights into the workout process of Austrian banks,

2. analyse the different strategies Austrian banks rely on to identify and manage distressed loans,

3. identify the criteria which influence the selection of loan workout strategies and

4. investigate whether or not the strategies employed among various types of banks differ according to strategic focus and/or size.

This way the present study's contributions to theory and practice are threefold. First, it sheds light on the rather neglected processes within banks to deal with distressed loans by providing insights into how banks organise the workout process and manage their problem loans. Second, the qualitative research design of the present study complements previous research that was exclusively quantitative in nature by allowing an in-depth and comprehensive analysis of the multifaceted cause and effect relations observed in the banks' workout strategies and thus a better understanding of the underlying processes, contents and dynamics. Third, our survey focuses on Austria, a country with a bank-based financial system that is hardly ever included in lending research (Kaufmann and Valderrama 2004). Banks are by far the predominant financial intermediaries in Austria's financial system (OeNB 2009) and they contribute a large portion of financing for non-financial corporations as well as private households (OeNB 2014). As in Germany (Brunner und Krahnen 2008), banks are normally directly involved in crisis management and play a dominant role in that process because of their extensive business relationships. Hence, the case of Austria provides a perfect example for studying the management of distressed loans. It adds to the existing body of knowledge by investigating the motives banks have to solve the distressed nature of the loan and subsequently avoid credit losses.

The structure of the paper is as follows: section two provides a literature review that focuses on the background to the Austrian banking sector, establishing what distressed loans are, the internal processes within a bank when dealing with distressed loans and lastly the different strategies bankers use when resolving distressed loans. Following this, the research methods are provided followed by the findings, the analysis and discussion of the findings and then the study concludes. 


\section{LITERATURE REVIEW}

\subsection{Austrian Banking Sector}

The Austrian banking sector is regarded as being universal in nature. Banks are by far the predominant financial intermediaries in the country's financial system (OeNB 2009) whereby the banks are organised by subsectors. Depending on their legal form and the traditional focus of their business, they are assigned to one of eight sectors including joint stock banks, savings banks, state mortgage banks and co-operative banks. Although this sectoral classification is still in use, it has rather historical roots and the distinctions between them have become increasingly blurred. With the exception of special purpose banks, Austrian banks offer the full range of banking products and services (OeNB 2004; OeNB 2009).

Differences amongst Austrian banks stem less from their affiliation with a certain sector than from their strategic orientation and whether or not they primarily focus on regional (one or certain Austrian regions) or international markets (various countries, including Austria). While the focus of savings, co-operative and mortgage banks have traditionally been regional, a few have grown in size and entered national and even international markets. The international Austrian banks have their main foreign business focus on the markets in Central, Eastern and Southeastern Europe (CESEE). After the fall of the iron curtain, Austrian banks have taken advantage of the historical ties and proximity to the CESEE countries and established subsidiaries as well as acquired local banks in these markets (OeNB 2009).

\subsection{Creditor-Borrower-Relationship and Distressed Loans}

Every lending relationship is characterised by information asymmetry (the borrower is better informed than the financier) and conflicting interests between the creditor and the borrower. The agency costs resulting from this situation can prevent a financing relationship a priori (adverse selection problem) or lead to the so-called moral hazard problem. Once the capital funds have been raised from outside creditors, the borrower has an incentive to misallocate these funds by using them in a way that benefits himself but not necessarily the lender(s). These problems are exacerbated in the case of distress. Due to the uncertainty inherent in a crisis situation the information asymmetry increases. Moreover, in distressed companies the quality of information that is available is often poor (Bris et al. 2006; Brunner and Krahnen 2008) and there are incentives of the managers for earnings management in their accounting choices (DeAngelo et al. 1994). In case of private borrowers this seems to be even worse. Of particular relevance in times of financial distress is the more likely opportunistic behaviour of the distressed borrowers given that they have, as it were, little to lose (Fischel 1989).

A formal definition of distressed loans is difficult to find. Within the ambit of so-called distressed loans, they are referred to as 'problem loans', 'delinquent loans', 'troubled loans', 'impaired loans', 'bad loans', 'nonperforming loans (NPLs)', 'sub-performing loans (SPLs)' or 'loans on watch list'. The terms are either used interchangeably or clustered together to reflect their relative degree of impairment. By en-large, distressed loans refer to those loans where the borrower fails to meet the contractual obligations to the lender. Since there is no wellrecognised international standard, the definitions of distressed loans vary widely across countries (Barisitz 2013; Beck et al. 2013). According to the proposal of the Institute of International Finance (cited in Beck et al. 2013), a bank's loan portfolio can be classified into five main groups, namely, standard, watch, substandard, doubtful and loss/write-off. While the broadest definition of NPLs comprises all categories of impaired loans, others rely on narrower classifications and only refer to the last two categories or only the loss loans (Dick 2010; Beck et al. 2013). The spectrum of problem loans can be divided into defaulted loans (narrowest definition of NPLs) for which a loss or write-off occurred and SPLs, for which some kind of impairment (e.g, amount in arrears) but no default occurred (see Figure 1 below). 
Figure 1. The spectrum of distressed loans within a bank's loan portfolio

\begin{tabular}{|c|c|c|c|c|}
\hline \multicolumn{3}{|c|}{ LOAN CATEGORIES } \\
\hline \multirow{2}{*}{ STANDARD } & WATCH-LIST & SUBSTANDARD & DOUBTFUL & LOSS \\
\cline { 2 - 4 } & \multicolumn{3}{|c|}{$\begin{array}{c}\text { Sub-performing loans } \\
\text { (SPLs) }\end{array}$} & $\begin{array}{c}\text { NPLs } \\
\text { (narrow definition) }\end{array}$ \\
\cline { 2 - 4 } & \multicolumn{3}{|c|}{$\begin{array}{c}\text { Non-performing loans (NPLs) } \\
\text { (wide definition) }\end{array}$} \\
\hline
\end{tabular}

Source: Authors

In Austria, the Financial Market Authority (FMA) issued the Minimum Standards for the Credit Business and other Transactions entailing Counterparty Risk (FMA-MS-K) in 2005 that provides "the Austrian credit institutions with guidelines on how to structure the credit business in terms of organisation and processes" (FMAMS-K 2005 paragraph 1). The FMA-MS-K (2005 paragraph 22b) recommend instructions and processing principles for intensified handling and the management of problem loans. Intensified handling should apply to loans whose risk assessment has deteriorated, but not to the extent that it is considered to be bad loans (FMA-MS-K 2005 paragraph 65). Consequently, intensified handling can be regarded as the pre-stage dealings of bad loans and the distinction between NPLs (in a narrow sense) and SPLs appears expedient.

NPLs (in a narrow sense) are defaulted loans. With regards to default, the Basel II accord (Basel Committee on Banking Supervision 2004 paragraph 452) specifies amongst other things that the obligor is past due more than 90 days. Especially this criterion of 90 days overdue is considered to be a "reference" and commonly used for classification (Rottke and Gentgen 2008; Beck et al. 2013). Apart from the number of days in arrears (which might also vary between countries), NPL classification criteria also take into account other dimensions such as whether or not bankruptcy or another judicial procedure has been started or indicates the financial performance of the debtor. There are also differences in delineation amongst these criteria, the treatment of collateral and guarantees, the classification of restructured loans and the assignment of multiple loans by one borrower (European Banking Coordination Vienna Initiative 2012; Beck et al. 2013). It should be noted that the definition of a 'defaulted loan' can be subjective. For example, Koch and MacDonald (2010:565) refer to a loan default as one where "the borrower has violated any loan covenants."

SPLs are considered loans that are impaired, but have not yet defaulted. They are typically characterised by a delay of payment of less than 90 days or, alternatively, a high probability of default (loans on watch list) (Froitzheim et al. 2006; Dick 2010). Banks often categorise as sub-performing those loans that are transferred to intensified handling (Schuppener 2006; Windhöfel 2006).

\subsection{Organisational Processes and Strategies to Resolve Distressed Loans}

Financial contracting theory attempts to overcome agency problems by designing the financing contract in a way that the interests of the capital seeker and the financier are aligned (contractual-based approach) and/or that allows numerous supervisory rights to be granted to the investor (monitoring-based approach). For this reason, the departure point for any bank with regards to it dealing with distressed loans is its formal loan policy. According to Koch and MacDonald (2010:555-556), the loan policy "formali[s]es lending guidelines [...] identifies preferred loan qualities and establishes procedures for granting, documenting, and reviewing loans." It therefore provides the blueprint from which bankers assess, manage, and, should it occur, deal with distressed loans. Part of the management of loans is to review their performance. Two functions ensure this, namely the monitoring of existing 
loans and the handling of distressed loans (Koch and MacDonald 2010). Should a borrower violate any covenant or specific stipulations of the original loan agreement, the bank is entitled to request immediate correction thereof. Should this not be possible, the loan becomes distressed and further action needs to be taken from the bank to recover any current or future losses.

The internal workout (or review) process banks use in order to deal with distressed loans is crucially important to ensure the speedy recovery and/or treatment of the loan. The longer such a loan is distressed, the more the resources needed by the bank to recover it. Banks must thus ensure that not only are the loans dealt with speedily, but that the bank does this without excessive losses. Therefore, banks often have specialised departments dealing specifically with distressed loans (Franks and Sussman 2005; Couwenberg and de Jong 2006).

Since distressed loans carry a higher degree of risk, they are unattractive because of the Basel II and III requirements (Basel Committee on Banking Supervision 2004, 2011). Apart from write-offs that impair profit and the balance sheet, these loans are associated with additional expenses that result from their monitoring, the negotiation of workout arrangements, the disposal of granted collateral and diverted focus of the bank's managers (Berger and DeYoung 1997). In Austria, the FMA-MS-K of 2005 intensify the requirements for banks in the lending process, and specifically, the management, monitoring and reporting of distressed loans in particular has been tightened significantly in recent years. The standards contain detailed instructions regarding the processing of SPLs and NPLs (FMA-MS-K 2005 paragraphs 65-71). Moreover, ad-hoc reporting requirements stipulate that bank managers and involved decision-makers must be informed immediately of any high-risk events that could threaten the bank from a risk perspective. For example, typical events include developments related to exceeding limits, creditworthiness deterioration and increased risk provisioning or write-offs to name only a few (FMA-MS-K 2005 paragraph 90). This implies that increasing personnel and other resources are tied to distressed loans, making them more unattractive to banks.

Generally, four main strategies to resolve distressed loans are typically used by banks. The most common strategy applied by banks is to establish and/or use their loan workout departments. This internal loan workout implies that the bank keeps distressed loans in-house and tries to resolve them by negotiating with the borrower. More specifically, loan workout is an "[a]ctivity [...] that focuses on delinquent loans and tries to develop and implement strategies designed to recover as much as possible from troubled borrowers" (Rose and Hudgins 2008: 688). This comprises all activities that range from the restructuring of the loan to its termination and the seizing of the borrower's collateral. However, the goal is to recover both current and future loan losses and requires hands-on handling of the distressed loan by committed workout specialists. Ideally, instead of, for example, liquidating assets of the troubled clients in order to recoup loan losses, banks would prefer restructuring the loan agreement in such a way that both the bank and the borrower are able to continue in their normal operations (Rose and Hudgins 2008).

Whether loan workouts are restructuring- or liquidation-oriented, they typically require intense negotiations between the bank and the borrower (Koch and MacDonald 2010). Therefore, the decision on whether or not to work out a distressed loan is often dependent on the strength of the banking relationship between the bank and the borrower. The notion of a so-called Hausbank (or main bank) not only reflects the commitment from the bank through troubled times (Elsas and Krahnen 1998), but also promotes investment and improves the performance of the borrower (Elsas and Krahnen 2004). Therefore, the stronger the Hausbank relationship, the more willing the bank is to work out the problem loan, especially if the distressed loan has a positive net present value (Elsas and Krahnen 2004).

Commonly used in German-speaking countries, a bank pool is a "legal institution aimed at coordinating lender interests in distress" (Brunner and Krahnen 2008:415). More specifically, a bank pool is defined as a formal contractual arrangement in which the participating banks pool their individual claims vis-á-vis a particular distressed borrower in order to coordinate their decisions and actions (Brunner and Krahnen 2008). In essence, bank pools enable multiple lenders the opportunity to collectively deal with distressed loans, which in turn implies that multiple banking relationships are dealt with simultaneously.

A further alternative for banks is to transfer the distressed loan to a so-called 'bad bank'. A bad bank is an efficient way to cleanse the balance sheet from distressed loans and thus "freeing the bank from the distraction, costs 
and use of resources inherent in managing a portfolio of troubled loans" (Ernst \& Young 2013:12). This bad bank approach has recently been used by several countries in Europe including Germany, Spain and Ireland (Ernst and Young 2013). In many cases state guaranteed, bad banks enable banks to reestablish financial market stability by removing the uncertainty within the banking sector (Freixas 2010; van Suntum and Ilgmann 2013).

Since the 1990s, a vibrant secondary market for bank loans has developed (Gande and Saunders 2012). Loan sales occur when a bank sells off its loans to specialised investors including for example other banks, insurance companies, pension funds or security dealers (Rose and Hudgins 2008). This allows banks to diversify their loan portfolios, comply with risk-adequacy regulations and redeploy capital to more profitable projects (Pennacchi 1988; Carlstrom and Samolyk 1995; Parlour and Plantin 2008; Drucker and Puri 2009) and seems extremely valuable in the case of distressed loans. Besides providing a source of cash from the sale, engaging in loan sales is usually done in order to get rid of low-yielding loans and reduce both credit and interest rate risk from the balance sheet of the bank (Rose and Hudgins 2008).

\section{RESEARCH METHODS}

Given that this paper attempts to explore in-depth the manner in which Austrian banks deal with the distressed loans (and the distressed clients) and to study in particular how they organise the workout process and select specific loan workout strategies, a qualitative research design seemed most appropriate. The Austrian banking sector is characterised by different types of banks, distinguished predominantly by sector, geographical strategic focus (either regional or international), size, and whether or not the bank is listed on the Vienna Stock Exchange. In order to identify whether or not different types of banks are incentivised to handle the relationship differently when attempting to workout distressed loans, a multiple case study approach (Eisenhardt 1989; Yin 2014) was most fitting to investigate the current modus operandi of Austrian banks with regards to identifying and managing distressed loans.

A diverse sampling strategy (Eisenhardt 1989) was adopted and a heterogeneous sample (Higginbottom 2004; Yin 2011; Patton 2015) selected that varied in several structural factors. This was done in order to gain diversified insights and to increase the (analytical) generalisability of the findings (Eisenhardt 1989; Yin 2014). A general overview of the sample banks and their characteristics in terms of strategic focus and size is presented in Table 1. One main selection criterion was the strategic focus of the bank, distinguishing between regional and international focus. This does not suggest that regional banks have no foreign customers or customers from other regions within Austria, but rather that they concentrate their business in the region where they are located. Conversely, the target market for international banks comprises many countries, with Austria being one of them. 
Table 1. The selection criteria used for the banks in the sample

\begin{tabular}{|c|c|c|c|c|c|c|c|c|}
\hline & \multicolumn{2}{|c|}{ STRATEGIC FOCUS } & \multicolumn{3}{|c|}{$\begin{array}{c}\text { SIZE (ASSETS) } \\
\end{array}$} & \multicolumn{3}{|c|}{$\begin{array}{l}\text { SIZE (EMPLOYEES) } \\
\end{array}$} \\
\hline & International & Regional & $>€ 50$ bn. & $€ 5-50 \mathrm{bn}$. & $<€ 5$ bn & $>5,000$ & $1,001-5,000$ & $\leq 1,000$ \\
\hline Bank A & 1 & & 1 & & & 1 & & \\
\hline Bank B & & 1 & & & 1 & & & 1 \\
\hline Bank C & & 1 & & 1 & & & 1 & \\
\hline Bank D & 1 & & 1 & & & 1 & & \\
\hline Bank E & & 1 & & 1 & & & 1 & \\
\hline Bank F & & 1 & & & 1 & & & 1 \\
\hline Bank G & & 1 & & 1 & & & 1 & \\
\hline Bank H & 1 & & 1 & & & 1 & & \\
\hline Bank I & & 1 & & & 1 & & & 1 \\
\hline Bank J & 1 & & & 1 & & 1 & & \\
\hline Bank K & & 1 & & 1 & & & & 1 \\
\hline Bank L & 1 & & & 1 & & & 1 & \\
\hline Total & 5 & 7 & 3 & 6 & 3 & 4 & 4 & 4 \\
\hline
\end{tabular}

Data were collected with the help of semi-structured interviews (Qu and Dumay 2011) in order to allow the respondents to give elaborate feedback and to ensure flexibility. Expert interviews (Rowley 2012) with the heads of the workout departments from the selected 12 Austrian banks were conducted in April, May and June of 2012. Given that these department heads are actively involved in the management of distressed loans (while simultaneously being senior executive management with decision-making authority), they are considered to be "key informants" (Kumar et al. 1993) and thus a vital source of information within the context of this study. The interviews lasted anywhere between 30 and 90 minutes per interview. On average, each interview lasted 67 minutes, with the median length 60 minutes. All of the interviews were digitally recorded and subsequently transcribed for analysis.

\section{FINDINGS}

\subsection{Defining Distressed Loans}

With regards to the classification of distressed loans, the respondents were asked to indicate which criteria they use to define a distressed loan. Since there is no uniform or required definition of distressed loans, the banks indicated that they rely on their own criteria. These criteria are documented in written form in 11 of the 12 banks, with only one regional co-operative bank having no formal written definition. More specifically, the criterion of arrears payments is most often relied on with nine (75\%) of the 12 banks using it. Six banks explicity refer to the Basel II default criteria or a delay of more than 90 days. The second most used criterion is the deterioration of the internal credit rating ( 5 banks). One third of the banks regard a loan as distressed if bankruptcy was filed. Two banks use the economic deterioration of the borrower, with one bank relying on adverse financial statement indicators.

Regarding whether or not banks made a distinction between NPLs and SPLs, four (of which three were international and one regional) indicated that they do not make any formal distinction, whereas the remaining eight separate the two. All of the respondent banks consider NPLs as being defined in the narrow sense of distressed loans and also as being likely causes of liquidations and/or bankruptcies. On the other hand, SPLs were considered to be at the stage prior to being regarded as non-performing and thus had a chance of recovery. As one banker puts it "[r] egarding SPLs there is a chance for rescue. As long as a 'hat is burning', you can extinguish it. When eventually the ashes are smoking, it is too late." 


\subsection{Internal Processes to Deal with Distressed Loans}

Eight banks (all five international banks and three regional banks) have more than one specialised unit dealing with distressed loans. Which unit the problem loan is assigned to depends on the type of loan and/or the relative degree of impairment. Furthermore, of the eight banks that distinguish between NPLs and SPLs four have more than one specialised unit and assign their SPLs to units specialised in intensive handling of the loan and then their NPLs to a further unit that focuses on more severely impaired loans. This is illustrated by the explanation of one banker: "Initially distressed loans are transferred to the 'Intensive Handling' unit, which is part of the Credit Risk Management Section (...). The loans located here are those that have been diagnosed with a 'disease' for the first time. In the Special Account Management [Sondergestion] unit we try to 'heal' the distressed loan. The third department, the Risk Administration [Risikoverwaltung] unit can be compared with a pathology department in a hospital, where loans are written off, liquidated and the collateral seized."

As opposed to the eight banks with multiple units dealing with distressed loans, three of the four remaining banks have only one specialised unit dealing with all types of distressed loans and the one remaining bank leaves these loans with the relationship banker. However, an expert is assigned to guide the relationship banker in dealing with the distressed loan. The names of these units are quite diverse. Even if banks use the same name, they do not always assign the same types of loans to this unit.

There are major similarities in the main tasks of the workout units amongst the participating banks. 11 of the 12 banks indicated that their workout unit accompanies the restructuring of the distressed borrower, with five (four of them regional banks) indicating that this was their primary task. As two department heads stated: "The most important task is restructuring" and "[o] ur philosophy is to get extensively involved to help the customer through the crisis." This finding therefore suggests that the workout units are primarily focused on assisting the client and finding a solution to the distressed nature of the loan. Hence, five banks also mentioned some form of intensive customer care such as active support, discussions and negotiations as one of the tasks of the specialised unit.

While the majority of regional banks consider restructuring the distressed borrower as the overarching objective, international banks strongly indicated if restructuring was not possible, that they would not restructure the loan at all costs. They further made it clear that the mindset adopted when restructuring is more often than not based on the facts they have before them in terms of potential losses to the bank. As one banker remarks "[i]t is not our primary goal to file bankruptcies, but to accompany firms in their restructuring endeavours. This, however, must go along with the risk position of the bank. This does not mean, restructuring at all cost." Another banker added "[g]enerally it is important to evaluate whether or not a loan can be reorganised. Repeat loan delinquencies are not the goal of the exercise." Since restructuring is not possible for all distressed borrowers, the task of seizing collateral (five banks) and the legal examination of the contractual relationship (four banks) were examples of alternative actions taken most often by the banks.

Since there is no legal definition that determines the conditions that require a bank to transfer distressed loans to the specialised workout unit, banks rely on different criteria to identify early warning signals of distressed loans. With eleven banks using a bundle of criteria, a deteriorating internal credit rating turned out to be the most important criterion and was applied by nine of the banks. Payments in arrears and/or liquidity problems were mentioned by five banks, and bankruptcy or near bankruptcy was a further criterion used by four banks. Although the banks do not all use the same criteria when deciding when to transfer distressed loans to the workout units, a common finding was that in order for the loan to be regarded as being 'normal' again, the internal credit rating of the distressed borrower must have improved, which implies that the profitability of the firm should have improved.

With regards to the process of managing distressed loans within the workout department, eight of the interviewed banks mention some form of more intensive and active care for the distressed borrower. For example, the banks indicated that during times of distress, the frequency of communication between them and the borrower increases substantially. This in turn resulted in a more thorough examination of the borrower's financial statements in order to assess any possibility of restructuring. Further to this, the banks also indicated that they examine the loan contract and/or collateral in detail and tend to tighten the loan prescriptions. These tightened conditions take several forms but increasing collateral requirements is used most often and a constant source of information as well as a 
shortening of loan application cycles is usually required. Although the FMA-MS-K (2005 paragraphs 65-71) stipulate instructions and processing principles for intensified handling and the management of distressed loans, it does not provide any detail on how banks should deal with these loans. The findings seem to indicate a vast array of processes that are followed.

Following how they deal with distressed loans, the respondent banks were asked to what extent the loans were separated from involving the personal banker who manages and services the (in this case distressed) client. Given that the minimum standards of the FMA (FMA-MS-K 2005, paragraph 68) require that the responsibility of restructuring, recovery and monitoring procedures of distressed loans does not lie with the front office, all interviewed banks adhere to this recommendation. If and to what extent the personal banker stays involved, however, varies amongst the banks. Seven banks transfer the distressed loan to the workout unit and do not give the personal banker a voice anymore. Four of these seven banks do not involve the personal banker at all after this transfer, whereas three provide some form of information flow between the workout unit and the personal banker. The remaining five banks either allow the personal banker generally or depending on the degree of impairment to stay involved. In three of them the personal banker stays the contact person for the distressed client and/or may express his opinion but has no decision-power anymore. For the remaining two banks the involvement depends on the degree of impairment. For example, one bank stated that " $[t]$ here are three categories of customer support in our bank: $A, B$ and $C$. $A$ is the toughest category: everything is done by the Special Account Management department, no matter what. In case of category $B$ the front office is involved in the determination of the terms and conditions of the loan, apart from that it has no decision authority. In category $C$ the front office is responsible for customer care, the Special Account Management department only participates."

Similarly, the other bank stated that "[d]ifferent departments are responsible for customer care in our bank. Intensive handling is done by the operative risk management, i.e. the colleagues who have a look on the loan contract at least once a year. In case of problem loans, these time limits are shortened. The risk manager accompanies the personal banker when he visits a customer and can require specific constraints on applications. He is not always intensively involved in the execution. This is the responsibility of the front office. If some form of loan restructuring is associated with problem loans, we [the Special Account Management Department] take over the function of the risk manager. We, however, deal more intensively with the loan and have to get an overview within a very short time period. We examine loan and collateral contracts and accompany [the personal banker] to the customer. We are full partners to the front office. We try to enable a restructuring, in whatever form this might be possible. This is very case specific. If we believe that the front office cannot contribute any further, we take over the case completely. We are alone responsible, negotiate alone and are therefore the only interface to this customer." This means that in the most severe form of distress, these two banks also do not allow any involvement of the personal banker.

Consequently, six of the banks (four of them international banks) do not involve the personal banker at all in the process once the loan has deteriorated to a certain degree and in another three banks (one international bank) the personal banker only gets informed and/or serves as a source of information for the workout unit. Only three banks, all of them regional banks, allow the personal banker to stay involved in the management of problem loans. This is illustrated by the following statements from these three regional banks: "The personal banker has a voice, as he is very close to the customer and knows him well"; "[t] he personal banker can present his opinion, but he is not allowed to decide. He is not released but has to continue to care for the customer. The procedure stays the same as with all other clients. The difference is that he no longer has decision authority"; and "[w] manage problem loans within the front office. The personal banker continues to be the contact person of the customer and is responsible for the administration. A specialist of the risk management department is by his side. Without this specialist he can do nothing."

As distressed loans pose higher constraints on the bank's capital requirements, the amount of time a bank regards a loan as being distressed is an important consideration. The respondents indicated that on average distressed loans spend between one and five years in the workout department depending strongly on the degree of distress. The general consensus was further that in case of restructurings, the timeframe tended to be shorter when compared to, for example, liquidations (especially if these involve bankruptcies). The responses also suggest that international and larger banks tend to keep distressed loans in the specialised units for shorter periods of time than the regional banks. 
The respondent banks were asked to indicate the size of the employee complement dealing with distressed loans in the workout department. In total, the number ranged from 10 to 120 employees in various stages of the workout. The responses also indicated a clear correlation between the size of the bank (in terms of employees) and the number of employees involved in the workout process. For example, the number of employees for the larger international banks ranges between 25 and 120 employees, whereas the smaller regional banks use between 10 and 72 employees. Even if this is self-evident, the lower number of specialised workout managers in smaller banks can explain the longer time that smaller regional banks take to work out a distressed loan. They have a smaller and thus less specialised staff complement available as a resource for workout, which increases the tendency to make the workout process more hands-on and personal with the distressed borrower.

\subsection{Strategies to Deal with Distressed Loans}

Regarding the strategies banks use to deal with distressed loans, all banks rely on the internal workout and all except for one regional bank form bank pools. Loan sales are used by four banks, three of which being large and medium-sized international banks and one a small regional bank. Although none of the banks use bad banks, one is currently considering establishing one.

Banks were then asked to identify why they chose the particular strategy to deal with distressed loans. Most of the banks indicated that the chosen strategy is dependent on the specific characteristics of the distressed loan (and indeed the distressed client) as well as the size of the outstanding loan and the number of parties the distressed borrower is liable to. Three banks suggested that they aim to maximise the recovery for the bank and therefore choose the strategy which promises the highest return. Four other banks later explained their decision for a certain strategy with the best results for the banks. Consequently, the bank's return is a major decision determinant. Eight of the banks (all seven regional banks) further added that the chosen strategy must be compatible with the philosophy of the bank at strategic level or its business model. This seems to suggest that loan sales and establishing bad banks are the exception rather than the preferred practice. The following statements from two different regional banks support these findings: "Our main strategy is to be the partner of our clients. It is therefore not advantageous to sell NPLs or outsource them to a bad bank. Following our business policy, it has been decided not to sell NPLs due to regional reasons. We do not want to take a sledgehammer approach; we would rather like to be perceived as a partner" and "[d]ue to our business strategy we are the client's partner. As such, we do not sell loans or outsource them to a bad bank, as good communication with the client is important to us. Our goal is to come to assist the client as much as possible."

Banks were then asked which criteria the distressed client has to meet in order to be able to further draw on his loan. Eleven banks argued that restructuring measures by the client are generally an important criterion that credit lines are maintained. Only one bank mentioned that this must not be the case and that it depends on the type of the loan and the collateral. Conversely, however, banks do not always call in the loan(s) if there are no restructuring measures. Instead, additional factors have to be met. These include a breach of the loan contract (default of payment, violation of covenants, mentioned by five banks) and/or a deteriorated or poor economic situation (three banks), which according to the standard business conditions of Austrian banks allows the bank to call in the loan, a hopeless situation of the borrower (four banks) and a loss of trust (two banks) or the lack of a basis for discussion (one bank). Regional banks in particular seem to be quite cautious to call-in distressed loans - four of the seven regional banks mentioned explicitly that the termination is considered as a measure of last resort. The different perspectives from respectively regional and international banks are illustrated by the following statements reflected in Table 2 . 
Table 2. Perspectives regarding the calling-in of loans

\section{STATEMENTS FROM REGIONAL BANKERS}

"If we as a bank have the impression that it is necessary to initiate measures in order not to worsen our situation, we call in the loan."

"Generally we call in loans, if there is a loss of trust, fraudulence and if collateral is held back. [...] The client takes measures that result in a lack of trust so that we cannot carry on. Due to this measure the trust gets lost and the creditworthiness deteriorates so that we do not like the borrower to be our client anymore. In this case we are improving our situation by calling in the loan."

"We do not become active and call in the loan immediately, except when the client acts irresponsibly. For example if the borrower transfers its receivables to someone else in case of a cession or if he violates the contract and removes collateral, we will not hesitate to terminate the loan. Generally, we do not cast the first stone as the Hausbank."

"If the client is willing to restructure his firm, even if this is the case in bankruptcy, then we will generally not call in the loan. If, however, there is no basis for discussion anymore, we will terminate the loan. This may be a step in order to secure our own interests. But it is the exception."

Source: Excerpts from interviews with Austrian banks

All except one bank use bank pools in dealing with distressed loans. In most cases, the establishment of the bank pool is not an explicit decision but follows rather from the fact that more than one bank is involved. This is illustrated by the following statement: "If there are several banks involved, we will form a bank pool in order to negotiate a collective approach and to communicate this jointly to the client. This way, we have a certain bargaining strength vis-á-vis the client. If there are bilateral transactions, we mostly decide for an internal workout, where we try to determine a restructuring strategy together with the client."

The importance of bank pools were therefore found to vary between banks. While all larger international banks consider bank pools as highly important and often take the lead, they are generally of medium importance to most regional banks. They were found to be of minor importance to one small regional bank and one international bank. A further small regional bank stated that it does not want to be involved in pools at all as "in recent years the co-operation with the other banks did not work out well."

With regards to the structuring of bank pools, most banks (eight) point out that the bank with the highest obligation (or amount outstanding) usually takes the lead in the pool. Apart from that, being the Hausbank (mentioned by five banks) and having a good relationship with the client (two banks) are of importance. A bank's collateralisation might also be relevant (mentioned by three banks), as one international bank argued: "One will participate in bank pools if we are relatively badly collateralised. If our bank is better secured than the other banks, we do not see a reason to participate in a bank pool."

Three banks mentioned that being the pool leader involves much effort. This implies that banks are generally not eager to take the lead in a bank pool. As one banker explains: "This is no task banks are keen on grabbing as it involves a lot of effort." As a result, most banks take different roles in bank pools depending on the specific situation they find themselves in. Two medium-sized regional banks, however, indicated that they prefer an active role in the process in order to better align their expectations and interests.

Banks form bank pools for several reasons. The most prominent reasons pertain to it ensuring a coordinated approach (six banks) and avoiding a race for premature contract termination (five banks). Two banks also value the feature that risk is distributed amongst the participants. Since a coordinated approach is central to a bank pool, banks 
emphasise the importance of a joint and mutual resolution: "It is not our strategy to enforce a better position for our bank compared to the other banks. You always meet at least twice. Naturally every bank struggles for optimisation but it becomes clear relatively soon where the upper and lower limits of one's counterparts are. Thus, the strategy of a bank pool is to find a constructive, joint solution, quasi to pull together. It is of no help for any bank to do their own thing." Contrary to this example there are banks that do so, as illustrated by the following statement: "There are banks we encounter regularly where one can leave when the pool gets formed as it is known that this bank is not prepared to engage in a constructive and collective solution." In this case the other banks usually take over the position of the 'stubborn' bank: "If one bank does not perform within the pool, the other banks have to take over. Moreover, in particular, small banks with low amounts outstanding wish to get out and are finally replaced."

Banks were then asked which strategy they deemed to be the most important. Loan workouts were considered the predominant and also preferred strategy of distressed loan management in nine of the interviewed banks. One bank relies on internal workouts and bank pools as predominant strategies. One bank (with a relatively high percentage of distressed loans) prefers loan sales as it associates the least effort with this strategy and values the fact that the balance sheet turnover gets reduced and part of the outstanding money paid. Internal workouts are also widespread in this bank. One bank remarks "The strategies mentioned are no either or. They are intertwined. One cannot say this measure is used more often than the other. It is like a puzzle where one has several parts that have to be assembled."

With regards to the advantages of the respective strategies, eight banks (two international, six regional banks) mention the importance of the relationship to the customer. Since the banks focus on the restructuring of the loan within their workout efforts and aim at restructuring the distressed client, they consider workouts and bank pools most suited to continue and strengthen the borrower-bank relationship. Statements such as "[t]he client does not fall away as it is the case with a loan sale or outsourcing to a bad bank. That is why we associate sustainability within the workout", "[b]y coming to the aid of the client to help him, the relationship with the client is strengthened" and "[t]he relationship with the client definitely grows within an internal workout" highlight the advantages with regards to the bank-client relationship within the workout process. Workouts are also preferred because banks consider them to bring about the best results, allow them an active involvement in the process and because of improved image reasons.

\section{ANALYSIS AND DISCUSSION}

The main findings concerning workout processes and strategies dealt with in the previous section are summarised in Table 3. 
Table 3. Insights from Interviews

\begin{tabular}{|c|c|}
\hline Theme & Findings \\
\hline $\begin{array}{l}\text { Defining distressed } \\
\text { loans }\end{array}$ & $\begin{array}{l}\text { - the vast majority of banks rely on the criterion of payments in arrears } \\
\text { other criteria used include the deterioration of the internal credit rating, bankruptcy filing and } \\
\text { worsening of the borrower's economic situation }\end{array}$ \\
\hline $\begin{array}{l}\text { Specialised workout } \\
\text { unit }\end{array}$ & 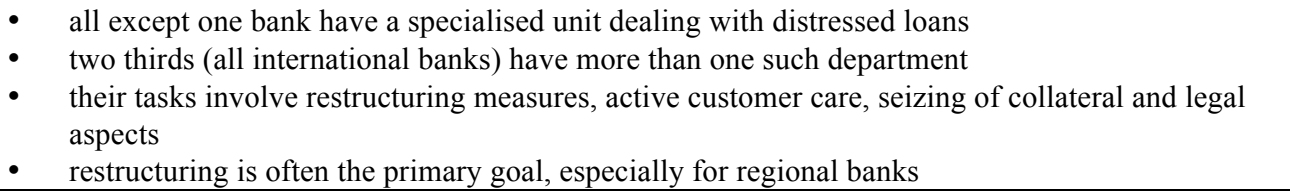 \\
\hline $\begin{array}{l}\text { Process of distressed } \\
\text { loan management }\end{array}$ & $\begin{array}{l}\text { - } \\
\text { - } \\
\text { - } \\
\text { increase intensive and active care for distressed borrower } \\
\text { - } \quad \text { tightening of communication } \\
\text { information flow and shortening of loan application cycles } \\
\end{array}$ \\
\hline $\begin{array}{l}\text { Involvement of } \\
\text { personal banker }\end{array}$ & $\begin{array}{l}\text { - majority of banks do not involve the personal banker at all once the loan has deteriorated to a } \\
\text { certain point, or only integrate the personal banker in the information flow } \\
\text { only three of seven regional banks allow the personal banker to stay involved as a contact person } \\
\text { with the client }\end{array}$ \\
\hline $\begin{array}{l}\text { Time in } \\
\text { workout unit }\end{array}$ & $\begin{array}{l}\text { - } \\
\text { - } \quad \text { in the case of restructurings the timeframe tends to be shorter than for liquidations } \\
\text { - } \quad \text { international and large banks appear to exhibit shorter workout timeframes }\end{array}$ \\
\hline $\begin{array}{l}\text { Strategies for } \\
\text { distressed loan } \\
\text { management }\end{array}$ & $\begin{array}{l}\text { - loan workouts are the predominant and preferred strategy of the majority of banks } \\
\text { - } \quad \text { regional banks are quite cautious to call in loans and consider this to be a measure of last resort } \\
\text { when the lender-borrower-relationship has deteriorated significantly } \\
\text { most banks participate in bank pools if the distressed client has several banking relationships; this } \\
\text { strategy is more important for larger international banks } \\
\text { - } \quad \text { strategy chosen must be compatible with the strategy of the bank } \\
\text { - relationship aspects are an important decision determinant, especially for regional banks }\end{array}$ \\
\hline
\end{tabular}

Although the vast majority of both regional and international banks send distressed loans through an internal workout process, international banks are more likely to call-in loans, and tend to do so a lot sooner than the regional banks do. One banker of a small regional bank even suggested that this practice will probably continue in the future: "The large international banks, that do not care about their image per se, remain unyielding. Once a client has landed in a certain risk class, liquidation follows. The smaller banks however have endlessly more patience. For them, the client matters and loan sales do not follow. The core competencies of regional banks focus on supporting a distressed borrower to heal through restructuring." Consequent to this, the interviews revealed that many regional banks indicated that the restructuring of distressed borrowers is seen to be an overarching principle in workout philosophy.

Since regional banks are in general more decentralised and thus geographically closer to their clients, the results of this study seem to complement the study of Micucci and Rossi (2010) who analysed loan relationships of Italian SMEs and found that debt restructurings are more likely 1) the higher the geographic proximity between the bank and the SME, 2) the more the bank considers 'soft' facts, and 3) the more decentralised the bank is. The findings suggest therefore that the international banks tend to be more 'hands-off' when dealing with distressed clients and are more likely to primarily consider the financial costs (and thus liquidate) than what the regional banks are. In an attempt to support and lead the restructuring of the distressed borrower, the regional banks tend to be more 'hands-on' with distressed borrowers. This result suggests that banks who tend to rely more on relationship lending (regional banks) as opposed to a more 'hands-off' transactional lending approach seem to invest more time and effort in the restructuring of their client. This is also consistent with the findings of Shimizu (2012) who found that shinkin banks (small co-operative banks in Japan that specialise in relationship loans to small, unincorporated firms) enhance the recovery rate of these firms from financial distress and reduce their bankruptcy ratios by having a higher volume of distressed loans in their portfolios and granting their clients an extension of the loan repayment this way. The more the ratio of distressed loans in shinkin banks excels those of the larger banks, the lower the bankruptcy ratio of unincorporated firms. 
Further to the tendency of regional banks to be more hands-on is the extent to which they use their resources to deal with distressed loans. All of the international banks have more than one specialised unit dealing with distressed loans, whereas the majority of regional banks tend to have only one unit which deals with all of the different types of distressed loans. There are several possible reasons explaining this. First, regional banks generally use less employees within their workout units suggesting that the workload per employee is higher. The resources regional banks have at their disposal are therefore a major constraint. Second, regional banks tend to keep distressed loans in the workout units for a longer period of time. In addition to being a result of fewer available resources, it can also be explained by their concerted, almost survivalist need to heal and recover distressed loans. Regional banks are more dependent on ensuring that distressed loans are recovered in order not to incur exorbitant financial losses. This follows that given the smaller loan portfolios of regional banks, they are more dependent on the recovery per unit than what the larger international banks are. Third, and encapsulating all of the above reasons, maintaining a hands-on relationship-based approach to dealing with their clients is important from a reputational point of view given their smaller loan portfolios and thus their reliance on the 'closeness' to their clients. It can be argued that the smaller regional banks would face larger relative losses caused by such reputational effects than the larger international banks would, merely due to the ability of international banks to absorb such losses. The fact that regional banks are more inclined to retain the services of the personal banker throughout the workout period pays testament to this. Further to this, given the larger market they function within, international banks are constantly weighing-up and exposed to new business opportunities, whereas regional banks have a smaller and somewhat limited market from which to get business. As a result, regional banks would be less inclined to terminate loans given the potential knock-on effect that it can have on the firm's suppliers and employees, who may in turn have accounts with the bank. Loan termination suggests having a more pervasive effect on regional banks than on larger international banks. For international banks, therefore, restructuring distressed loans is not at any cost.

While regional banks might indeed value relational aspects higher, it should be borne in mind that the quality and extent of the collateralisation is just as important. As one regional banker put it: "[Terminating the loan] is the last resort. We only harm ourselves if we do this as most cases are on the verge of bankruptcy and we are seldom if ever $100 \%$ secured."

Having a specialised unit that deals with distressed loans seems to pay off as the share of distressed loans within the total portfolio seems to be lower in banks that established their workout units earlier and therefore had the ability to adjust their portfolios and take care of these loans more intensively. This is also explained by one banker: "Previously problem loans stayed with the personal banker. Dealing with them, however, was difficult in the normal process of customer care. On the one hand, distressed loans require more intensive care and on the other it is extremely difficult to switch roles between being the personal banker and the restructurer."

At the heart of managing distressed loans lies the intention to reduce information asymmetry and the incentives of the borrower to misallocate the received funds. This intention is observed in our study. The interviewed banks deal more intensively with the distressed borrower, analysing the client more thoroughly and/or enforcing, for example, increased collateral requirements or tightening covenants. This way they attempt to reduce the information asymmetry and the concomitant risk that is inherent to the distressed nature of the loan. The enforcement of these covenants also assists to reduce the opportunistic behaviour of the distressed client and thereby ensures that the interests of the bank and the borrower are (more) aligned. This tightening of covenants complements previous studies amongst US companies that also experienced more restrictive loan conditions as a result of financial distress (Gilson 1990). It also corroborates the findings of Harhoff and Körting (1998) that financial distress results in higher collateral requirements for German SMEs.

With regards to the type of strategy banks use to deal with distressed clients, bank pools seem to be of the highest importance for the larger international banks, whereas for the small and medium-sized banks they play a lesser role. This can be explained with the fact that they are less involved in large loans due to the statutory limit for amounts of single loans. However, banks that participate regularly in bank pools and who consider them of higher importance tend to have lower ratios of distressed loans. On the contrary, if bank pools play no or a minor role, this is associated with a trend toward a higher ratio of non- and sub-performing loans. When a bank participates in a pool, a joint solution is targeted and efforts are combined. Therefore, a bank that is not part of the pool might have its distressed loans in the portfolio for a longer period, which in turn exacerbates its problem loan ratio. 
In theory, the sale of distressed loans is an important alternative in the management of problem loans. But only three of the five interviewed international banks and one regional bank use this option. On the other hand, most of the banks operating regionally cannot imagine making sales of distressed loans because of their strategy and their concern for the relationship with the client. All banks (except for one international bank) that do loan sales have relatively high ratios of distressed loans. Hence, the majority of these banks use loan sales in order to reduce their problem loans. This might also elucidate why one regional bank uses loan sales and simultaneously points out its opposition to loan sales - even if this is a profitable option - because of their strategy. This contradiction may be explained when the interviewed banker states that currently they experience a decrease in financial resources due to the loss of trust amongst savers that they can use for lending and that he expects no loan sales in regional banks in the future. Taking this and the fact into account that there is only a very small number of loan transactions per year in this bank, loan sales might be used as a way of freeing up capital for better loan deals but are not considered as an important strategy in managing distressed loans.

\section{CONCLUSION}

Distressed loans are an important managerial consideration for banks and need to be dealt with in a manner that ensures that the bank has minimal losses, from both a financial and reputation point of view. This paper provided evidence of how a sample of different banks in the Austrian economy deals with such distressed loans.

Loan workouts were found to be the predominant and preferred strategy for dealing with distressed loans, followed by bank pools. Since interviewees tend to favour options that assist the client to overcome the distressed nature of the loan and to continue the bank-borrower relationship, these two options seem most suited. Investigating the relational aspect of loan workouts further, regional and smaller banks in particular stress the relationship to their customer as an important decision determinant and seem to be more inclined to salvage the distressed loans. Moreover, the study found that smaller regional banked tended to use the relationship banker more actively in the process than larger international banks did. This finding highlights the importance of ensuring that the 'healing' of distressed loans is prioritised in the name of (financial) survival as well as minimising reputational effects. All in all, the smaller regional banks were found to be more 'hands-on' when dealing with their distressed loans than the larger international firms tended to be.

Our findings may be relevant for banks and bank clients. Regarding the implications for banks, our results indicate that banks with larger and more specialised workout units exhibit lower ratios of distressed loans. Consequently, establishing a specialised task force with corresponding resources seems advisable. Second, banks that participate regularly in bank pools and consider these important have also lower ratios of impaired loans. Therefore, bank pools appear an adequate approach for co-ordinating the measures of the involved banks. For distressed clients it is important to understand the logic behind banks' strategies in crisis situations. Banks rely on a vast array of processes in order to handle distressed loans. Most of them are intended to reduce the aggravated agency problems associated with the crisis. Consequently, distressed borrowers can proactively send positive signals to the bank through active communication, disclosures, implementation of restructuring measures etc. in order to convince the bank of the seriousness of their efforts and to reduce information asymmetry. Since several interviewed Austrian banks consider the termination of a loan as a measure of last resort, there still seems to be a high willingness among banks to help their distressed borrowers. Hence, ailing clients have to demonstrate that there are realistic turnaround prospects. Finally, the time in the workout department is related to the degree of impairment and tends to be shorter for restructurings. This indicates that the chances for success - from the client's as well as the bank's perspective - are higher the earlier counter measures are initiated. Consequently, banks should improve their early warning systems to detect impaired loans at an early stage. Concomitantly, borrowers should also be aware of the benefits of proactively approaching banks in case of distress and of initiating turnaround measures in time.

In conclusion, a limitation to this study is that given its qualitative nature it is by no means representative of the entire Austrian banking sector. The findings do however provide valuable insights with regards to the processes and conduct of different types of banks to deal with distressed loans. Further research could be focused on comparing the results of this study to other European countries, especially those that have banks with active regional and international operations. A further study could also focus on identifying the specific quantitative criteria banks use to identify and manage distressed loans. This should create a situation where distressed borrowers are more 
aware of the indicators banks rely on to identify problem loans and result in better management on the part of the borrower.

\section{AUTHOR INFORMATION}

Dr. Christine Mitter is Professor of Management Accounting and Finance in the Business Program at the University of Applied Sciences in Salzburg, Austria and a Lecturer of Management Accounting at Johannes Kepler University of Linz, Austria, where she earned her PhD.

Andrea Weidinger, took her bachelor's degree in Banking and Finance at the University of Applied Sciences Bfi Vienna and completed her master's degree in Business Management at the Salzburg University of Applied Sciences. Currently she is working in the field of Factoring at RZB Group.

Dr. Johan Coetzee is a senior lecturer at the Department of Economics and Business School at the University of the Free State in South Africa. He is a visiting senior lecturer in banking at the Salzburg University of Applied Sciences in Austria and is currently an external board member for the Milpark Banking School and a consultant in bank risk management to the South African Reserve Bank College in Pretoria. E-mail: CoetzJ@ufs.ac.za

\section{REFERENCES}

Altman, E.I. 2014. The role of distressed debt markets, hedge funds and recent trends in bankruptcy on the outcomes of chapter 11 reorganizations. ABI Law Review, 22 (1), pp. 75-123.

Barisitz, S. 2013. Nonperforming Loans in Western Europe - A Selective Comparison of Countries and National Definitions, Focus On European Economic Integration, Q1/13, pp. 28-47.

Basel Committee on Banking Supervision. 2004. International convergence of capital measurement and capital standards, June, Bank for International Settlements.

Basel Committee on Banking Supervision. 2011. Basel III: A global regulatory framework for more resilient banks and banking systems - revised version, June, Bank for International Settlements.

Beck, R., Jakubik, P. and Piloiu, A. 2013. Non-performing loans: What matters in addition to economic cycles? European Central Bank, Working Paper No. 1515, Frankfurt/Main.

Berger, A.N. and DeYoung, R. 1997. Problem loans and cost efficiency in commercial banks. Journal of Banking \& Finance, 21 (6), pp. 849-870.

Blazy, R., Martel, J. and Nigam, N. 2014. The choice between informal and formal restructuring: The case of French banks facing distressed SMEs. Journal of Banking \& Finance, 44, pp. 248-263.

Bris, A., Welch, I. and Zhu, N. 2006. The Costs of Bankruptcy: Chapter 7 Liquidation versus Chapter 11 Reorganization. Journal of Finance, 61 (3), pp. 1253-1303.

Brunner, A. and Krahnen, J.P. 2008. Multiple Lenders and Corporate Distress: Evidence on Debt. Review of Economic Studies, 75 (2), pp. 415-442.

Carlstrom, C.T. and Samolyk, K.A. 1995. Loan sales as a response to market-based capital constraints. Journal of Banking \& Finance, 19 (3-4), pp. 627-646.

Chaibi, H. and Ftiti, Z. 2015. Credit risk determinants: Evidence from a cross-country study. Research in International Business and Finance, 33, pp. 1-16.

Couwenberg, O. and de Jong, A. 2006. It takes two to tango: An empirical tale of distressed firms and assisting banks, International Review of Law and Economics, 26 (4), pp. 429-454.

Davydenko, S.A. and Franks, J.R. 2008. Do Bankruptcy Codes Matter? A Study of Defaults in France, Germany and the U.K. Journal of Finance, 22 (10-11), pp. 565-606.

DeAngelo, H., DeAngelo, L. and Skinner, D.J. 1994. Accounting choice in troubled companies. Journal of Accounting and Economics, 17 (1-3), pp. 113-143.

Dick, M. 2010. Der Verkauf von Non Performing Loans. Eine Analyse von NPL-Transaktionen aus Bankensicht. Gabler: Wiesbaden.

Drucker, S. and Puri, M. 2009. On Loan Sales, Loan Contracting, and Lending Relationships, Review of Financial Studies, 22 (7), pp. 2835-2872. 
Eisenhardt, K.M. 1989. Building Theories from Case Study Research. Academy of Management Review, 14 (4), pp. 532-550.

Elsas, R. and Krahnen, J.P. 1998. Is relationship lending special? Evidence from credit-file data in Germany, Journal of Banking \& Finance, 22 (10-11), pp. 1283-1316.

Elsas, R. and Krahnen, J.P. 2004. Universal banks and relationships with firms, in: Krahnen, J.P. and Schmidt, R.H. (eds.), The German Financial System, Oxford: Oxford University Press.

Ernst \& Young. 2013. Flocking to Europe: Non performing Loan Report.

European Banking Coordination Vienna Initiative. 2012. Working Group on NPLs in Central, Eastern and Southeastern Europe, March.

Filip, B.F. 2014. Non-performing loans - dimension of the non-quality of bank lending/loans and their specific connections. Theoretical and Applied Economics, 21 (5), pp. 127-146.

Fischel, R.D. 1989. The Economics of Lender Liability. Yale Law Journal, 99 (1), pp. 131-154.

FMA (Financial Market Authority). 2005. FMA Minimum Standards for the Credit Business and other Transactions entailing Counterparty Risks of 13 April, 2005 (FMA-MS-K), Vienna.

Franks, J. and Sussman, O. 2005. Financial Distress and Bank Restructuring of Small to Medium Size UK Companies. Review of Finance, 9 (1), pp. 65-96.

Freixas, X. 2010. Post-crisis challenges to bank regulation. Economic Policy, 25 (62), pp. 377-399.

Froitzheim, R., Lotz, U., Breiteneicher, J., Nachtwey, T. and Leclaire, A. 2006. Non Performing Loans (NPL) in Deutschland: Praxisrelevante Aspekte, Instrumente zur Abgabe von notleidenden Krediten und Bedeutung für die Banksteuerung. Bank-Verlag: Cologne.

Gande, A. and Saunders, A. 2012. Are Banks Still Special When There Is a Secondary Market for Loans? Journal of Finance, 67 (5), pp. 1649-1684.

Gilson, S.C. 1990. Bankruptcy, Boards, Banks, and Blockholders: Evidence on Changes in Corporate Ownership and Control When Firms Default. Journal of Financial Economics, 27 (2), pp. 355-387.

Harhoff, D. and Körting, T. 1998. Lending relationships in Germany - Empirical evidence from survey data. Journal of Banking \& Finance, 22 (10-11), pp. 1317-1358.

Higginbottom, G.M. 2004. Sampling issues in qualitative research, Nurse Researcher, 12(1), pp. 7-19.

Istrate, E., Gupta, D.D. and Weissburg, P. 2007. Towards Developing a Structured Approach to the Diagnosis and Resolution of Nonperforming Loans: The Case of China and India. Review of Policy Research, 24 (4), pp. 345-365.

Kaufmann, S. and Valderrama, M.T. 2004. The Role of Bank Lending in Market-Based and Bank-Based Financial Systems. Monetary Policy \& the Economy, Q2/04, pp. 88-97.

Koch, T.W. and MacDonald, S.S. 2010. Bank Management. $7^{\text {th }}$ edition, South-Western, Cengage Learning: Mason Ohio.

Kumar, N., Stern, L.W. and Anderson, J.C. 1993. Conducting Interorganizational Research Using Key Informants. Academy of Management Journal, 36 (6), pp. 1633-1651.

Louzis, D.P., Vouldis, A.T. and Metaxas, V.L. 2012. Macroeconomic and bank-specific determinants of nonperforming loans in Greece: A comparative study of mortgage, business and consumer loan portfolios. Journal of Banking \& Finance, 36 (4) pp. 1012-1027.

McIver, R. 2005. Asset Management Companies, State-Owned Commercial Bank Debt Transfers and Contingent Claims: Issues in the Valuation of China's Non- Performing Loans. Managerial Finance, 31 (12), pp. 11 28.

Micucci, G. and Rossi, P. 2010. Debt Restructuring and the Role of Lending Technologies, Working Paper, Banca d'Italia, No.76, Ancona and Milan.

Nkusu, M. 2011. Nonperforming Loans and Macrofinancial Vulnerabilities in Advanced Economies, IMF Working Paper, WP/11/161.

OeNB (Austrian National Bank). 2004. The Austrian Financial Markets: A Survey of Austria's Capital Markets. OeNB Facts and Figures, Revised Edition, Vienna.

OeNB (Austrian National Bank). 2009. Banking Supervision in Austria, Vienna.

OeNB (Austrian National Bank). 2014. 13. Kreditbericht, Entwicklung der Kredite des österreichischen Bankensystems an den Unternehmenssektor, Vienna.

Parlour, C.A. and Plantin, G. 2008. Loan Sales and Relationship Banking. Journal of Finance, 63 (3), pp. 12911314.

Patton, M.Q. 2015. Qualitative Research \& Evaluation Methods, $4^{\text {th }}$ edition. Sage: Thousand Oaks, CA. 
Pennacchi, G.G. 1988. Loan Sales and the Cost of Bank Capital. Journal of Finance, 43 (2), pp. 375-396. Qu, S.Q. and Dumay, J. 2011. The qualitative research interview. Qualitative Research in Accounting \& Management, 8 (3), pp. 238-264.

Rose, P.S. and Hudgins, S.C. 2008. Bank management and financial services, 7 th edition, McGraw-Hill Irwin: New York.

Rottke, N.B. and Gentgen, J. 2008. Workout management of non-performing loans: A formal model based on transaction cost economics. Journal of Property Investment \& Finance, 26 (1), pp. 59-79.

Rowley, J. 2012. Conducting research interviews. Management Research Review, 35 (3-4), pp. 260-271.

Schäfer, S. 2007. "Non-performing loans" - an established asset class. Deutsche Bank Research, Frankfurt/Main.

Schalast, C., Ockens, K., Jobe, C.J. and Safran, R. 2006. Work-Out und Servicing von notleidenden Krediten Berichte und Referate des HfB-NPL Servicing Forums 2006. Working Paper Series, HfB No. 76, Frankfurt/Main.

Schuppener, J. 2006. Einführung - Markt, Teilnehmer und Marktentwicklung. In: Lützenrath, C., Peppmeier, K. and Schuppener, J. (eds.): Distressed Debt und Non- Performing Loans: Handel und Workout von Not leidenden Firmenkundenkrediten in der Bankpraxis. Gabler: Wiesbaden, pp. 11-25.

Shehzad, C.T., de Haan, J. and Scholtens, B. 2010. The impact of bank ownership concentration on impaired loans and capital adequacy. Journal of Banking \& Finance, 34 (2), pp. 399-408.

Shimizu, K. 2012. Bankruptcies of small firms and lending relationships. Journal of Banking \& Finance, 36 (3), pp. $857-870$.

van Suntum, U. and Ilgmann, C. 2013. Bad banks: a proposal based on German financial history. European Journal of Law and Economics, 35 (3), pp. 367-384.

Windhöfel, T. 2006. Arten der Übertragung von Kreditforderungen und rechtliche Rahmenbedingungen. In: Lützenrath, C., Peppmeier, K. and Schuppener, J. (eds.): Distressed Debt und Non-Performing Loans: Handel und Workout von Not leidenden Firmenkundenkrediten in der Bankpraxis. Gabler: Wiesbaden, pp. 89-117.

Yin, R.K. 2011. Qualitative Research from Start to Finish. The Guilford Press: New York. Yin, R.K. 2014. Case study research. Design and methods. $5^{\text {th }}$ edition. Sage: Los Angeles. 